\title{
TWO NEW EARTHWORM SPECIES (Oligochaeta, Megascolecidae) FROM VIETNAM
}

\author{
Nguyen Thanh Tung \\ Can Tho University, Can Tho city, Vietnam
}

\begin{abstract}
Two new earthworm species are described from An Giang Province, southern Vietnam. Metaphire nhuongi sp. $\mathrm{n}$. is distinguished from its congeners by having four pairs of spermathecal pores in lateroventral intersegments 5/6/7/8/9, and two pairs of genital markings in $17 / 18$ and 18/19. Polypheretima alba sp. $\mathrm{n}$. is recognized by multiple spermathecal pores in dorsal intersegments 4/5/6/7, genital markings 4-6 pairs on xix-xxiii, and body whitish.
\end{abstract}

Keywords: Megascolecidae, Metaphire, Polypheretima, earthworms, new species, Vietnam.

Citation: Nguyen Thanh Tung, 2016. Two new earthworm species (Oligochaeta, Megascolecidae) from Vietnam. Tap chi Sinh hoc, 38(4): 442-448. DOI: 10.15625/0866-7160/v38n4.8829.

*Corresponding author: thanhtung@ctu.edu.vn.

Received 2 November 2016, accepted 20 December 2016

\section{INTRODUCTION}

An Giang is located in the Cuu Long river delta of the southernmost part of Vietnam. Its area is about $3,406.23 \mathrm{~km}^{2}$ with a majority part of delta (accounting for $87 \%$ its area) while hilly regions account for only $13 \%$. Climate is moonsoon tropical with annual average temparate of $27^{\circ} \mathrm{C}$, and two seasons: rainy one (from May to November) and dry one (from December to next April) (Le Thong, 2006). The fauna and flora of the region are very diverse, and many new species have been discovered recently (Nguyen Thanh Tung, Tran Thi Anh Thu, 2008).

To date, 18 earthworm species belonging to 9 genera, 5 families have been reported from An Giang province (Nguyen Thanh Tung et al., 2012). Of these species, four were previousely described: Metaphire mangophila (Nguyen, 2011); Metaphire baii (Nguyen, 2011); Metaphire dorsomultitheca Nguyen \& Nguyen, 2015 and Amynthas nhonmontis Nguyen \& Nguyen, 2015. This paper is devoted to describe two more new earthworm species from An Giang Province, Vietnam.

\section{MATERIALS AND METHODS}

Materials were collected from top soil layer.
Earthworms were firstly cleaned by tap water, killed with $2 \%$ formalin, and then fixed in $4 \%$ for 12 hour. All specimens were preserved in $4 \%$ formalin.

Specimens were directly observed under the microscope Motic DM143 FBGG C. Images were taken using the camera attacted to the microscope. Line drawings were made based on the observation under the microscope. All images were grouped using the Photoshop CS6.

Holotypes and paratypes are deposited in the Laboratory of Zoology, Department of Biology, Can Tho University (=CTU), Can Tho city, Vietnam.

\section{RESULTS AND DISCUSSION}

Metaphire nhuongi Nguyen, sp. n. (Fig. 2)

Examined material: Holotype: 1 mature (CTU-EW.024.h01), natural forest $\left(10^{\circ} 18^{\prime} 07.4^{\prime \prime} \mathrm{N} ; \quad 104^{\circ} 32^{\prime} 06.1^{\prime \prime} \mathrm{E}\right), \quad$ Co $\quad$ To mountain, Tri Ton district, An Giang Province, 09/11/2010, coll. Nguyen Thanh Tung. Paratypes: 6 matures (CTU-EW.024.p02), same data as holotype; 2 matures (CTUEW.024.p03), Phu Cuong mountain $\left(10^{\circ} 35^{\prime} 02.0^{\prime}{ }^{\prime} \mathrm{N} ; \quad 104^{\circ} 56^{\prime} 07.8^{\prime \prime} \mathrm{E}\right)$, Tinh Bien District, An Giang province, 7/11/2010, coll. Nguyen Thanh Tung. 


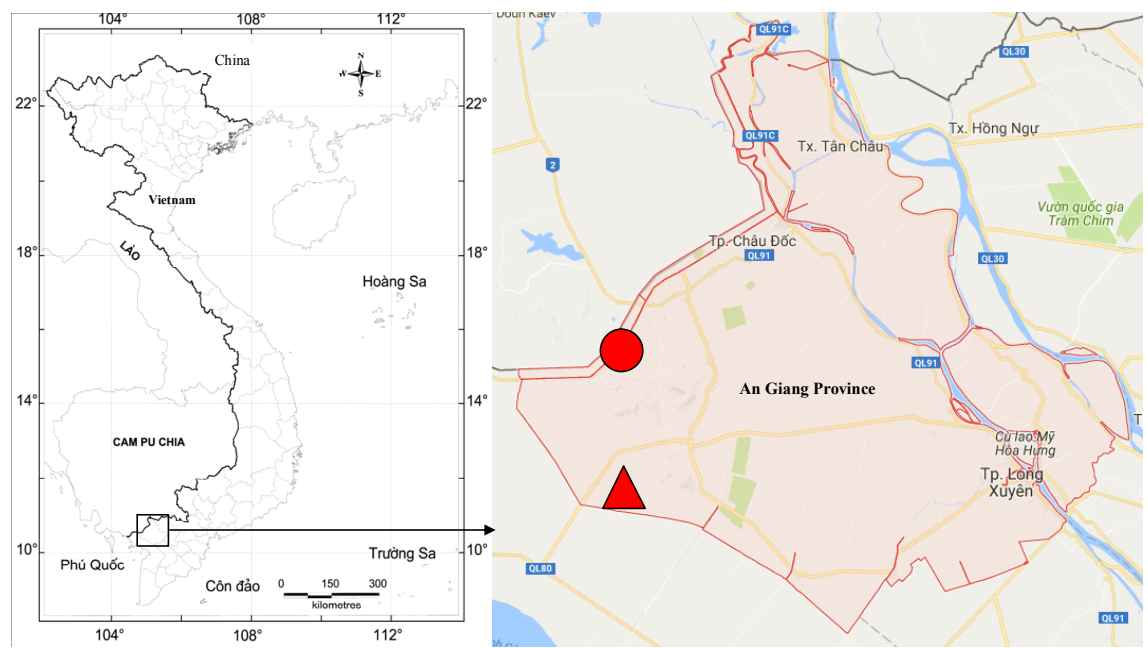

Figure 1. Collection sites of two new earthworms

(•: Metaphire nhuongi; $\mathbf{\Delta}$ : Metaphire nhuongi \& Polypheretima alba)
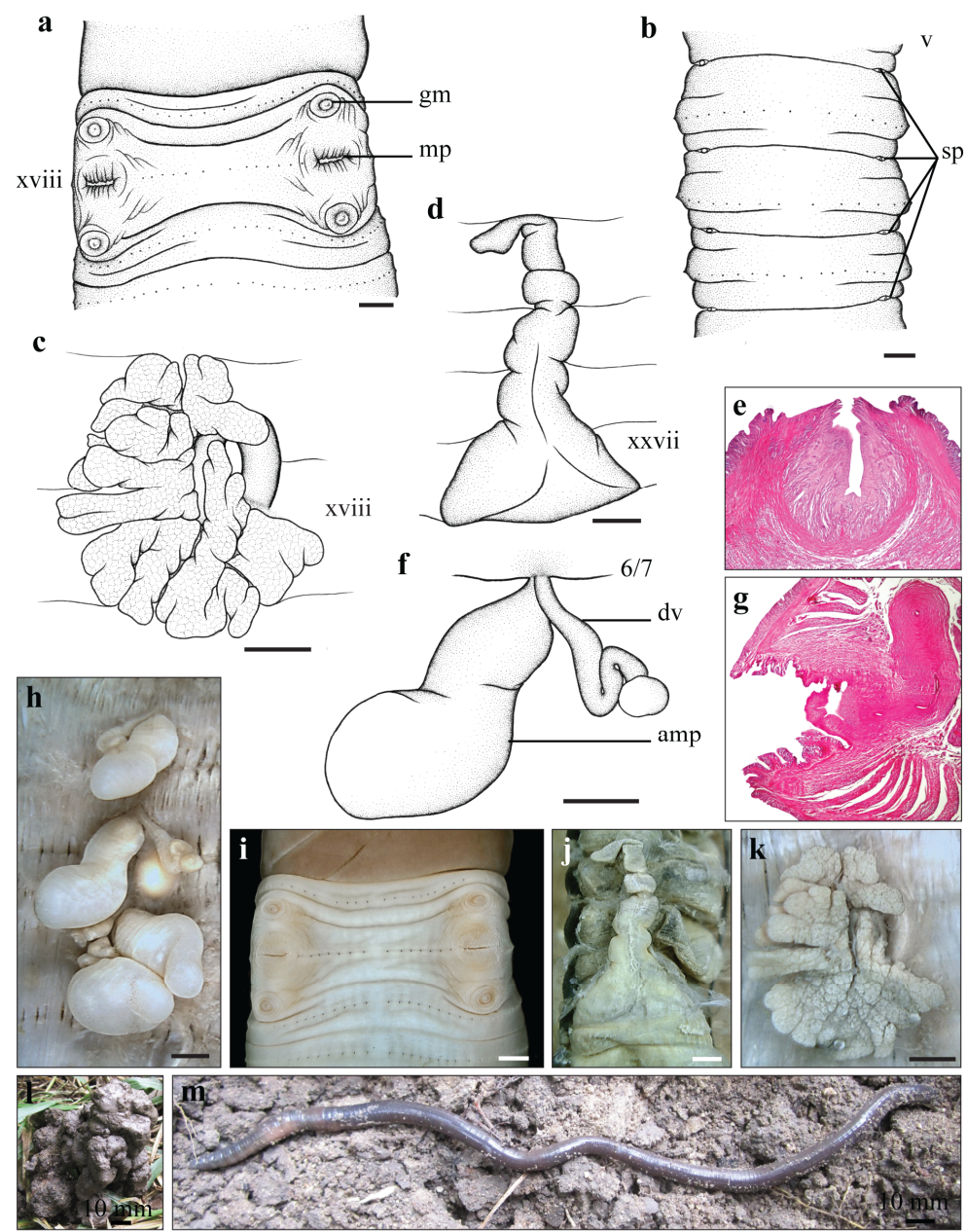

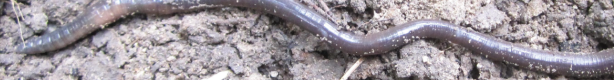

Figure 2. Metaphire nhuongi Nguyen, sp. n.

$\mathrm{a}, \mathrm{i}$ : Male pore region (mp $=$ male pore, $\mathrm{gm}=$ genital marking); b: Spermathecal region, ventral view $(\mathrm{sp}=$ spermathecal pore);

c, k: Prostate gland;

$\mathrm{d}, \mathrm{j}$ : Intestinal caeca; e: Accessory gland, transverse body section; f: Spermathecae $(\mathrm{amp}=$ ampulla, $d v=$ diverticula); g: Copulatory pouch, transverse body section; $\mathrm{h}$ : Spermathecae in right side; 1: Casts; m: Alive mature. Scale bar $=1 \mathrm{~mm}$. 
Diagnosis: Large size worm, length 213$339 \mathrm{~mm}$, diameter ca. 8.9-9.5 mm. First dorsal pore in 12/13. Spermathecal pores lateroventrally paired in intersegmental furrows $5 / 6 / 7 / 8 / 9$. Genital marking paired in $17 / 18$ and $18 / 19$. Holandric. Intestinal caeca simple. Septa 8/9/10 absent.

Etymology: Named after Dr. Do Van Nhuong, a prominent researcher on earthworms in Vietnam.

Description: External characters: Body cylindrical, large; length 213-339 mm, diameter ca. 8.9-9.5 mm, weigt $10.68-22.50 \mathrm{~g}$, segments 120-148. Dorsal blackish grey, ventral paler. Prostomium epilobous (2/3). Setae perichaetine, short; pre-clitellar setae stouter and sparser than post-clitellar setae, 45-51 in viii, 53-75 in xxx, 14-15 between male porophores in xviii; setae distance $\mathrm{aa}=1.2-1.5 \mathrm{ab}, \quad \mathrm{zz}=1.5-2.0 \mathrm{zy}$. Clitellum annular, xiv-xvi, blackish brown, smooth, without setae and dorsal pores. Female pore single, mid-ventral on xiv.

Spermathecal pores four pairs, lateroventral in intersegmental furrows 5/6/7/8/9. Genital markings absent in the spermathecal region. Male pores paired in xviii, ventrolateral; copulatory pouches present; ventral distance between male pores about $0.33 \mathrm{x}$ body circumference. Two pairs of small, round genital markings in intersegments $17 / 18$ and $18 / 19$, respectively, in line with male pores.

Internal characters: Septa 5/6/7/8 thickened, 8/9/10 absent, 10/11/12/13 thin. Oesophageal gizzard large, within viii-ix. Intestinal origin at $\mathrm{xv}$; caeca simple, within xxvii-xxii or xxvii-xxiii. Last hearts in xiii. Pharyngeal micronephridia well developed in 4/5/6. Lymph glands from 15/16. Typhlosole simple, lamelliform.

Spermathecae paired in vi-ix. Spermathecal ampulla mango-shaped, duct extremely short or almost absent. Diverticula shorter than ampulla, waved in the middle, attached to ampulla at base; distal part enlarged to be an oval-shaped, opalescent seminal chamber. Accessory glands absent in the spermathecal region.

Holandric, testes sacs ventrally paired in $\mathrm{x}$ and $\mathrm{xi}$, separated and yellowish. Seminal vesicles developed in xi and xii. Ovaries well developed in 12/13. Ovisacs small in 12/13. Prostate glands racemose, deeply lobuled, paired within xvii-xix; prostatic ducts short and stout. Accessory glands absent in the male region.

Locality and habitat: The new species was commonly found in a mango garden in Phu Cuong Mountain (Tinh Bien District) and Co To Mountain (Tri Ton District). Soils are medium clays. Their casts form big piles on soil surface, but not lumps.

Remarks: The new species is fairly similar to M. peguana (Rosa, 1890), M. pacseana (Thai \& Samphon, 1988) và M. stephensoni (Michealsen, 1934b) in having two pairs of genital markings in $17 / 18$ and $18 / 19$, no genital markings on the spermathecal region, prostomium epilobous and septa 8/9/10 absent. However, $M$. nhuongi sp. nov. can be recognized by its larger size (diameter ca. 8.9$9.5 \mathrm{~mm}$ ) and having four pairs of spermathecal pores in 5/6/7/8/9.

In addition, the new species is closely similar to M. anhumalatana (Thai \& Huynh, 1993), M. dalatana (Michaelsen, 1934b), M. langbiangi (Michaelsen, 1934b), M. seponensis (Thai \& Samphon, 1989), M. bianensis (Stephenson, 1931) in having four pairs of spermathecal pores in intersegments 5/6/7/8/9. However, the new species differs from those species in larger size (diameter ca. 8.9-9.5 mm) and having two pairs of genital markings in $17 / 18$ and $18 / 19$, while other similar species are smaller (diameter less than $8 \mathrm{~mm}$ ) and no genital markings on the male region.

Polypheretima alba Nguyen, sp. n. (Fig. 3, Table 1)

Examined material: Holotype: 1 mature (CTU-EW.101.h01), long-term tree garden $\left(10^{\circ} 23^{\prime} 27.2^{\prime} \mathrm{N}^{\prime}\right.$; $\left.104^{\circ} 59^{\prime} 56.1^{\prime \prime} \mathrm{E}\right), \quad \mathrm{Co} \quad$ To mountain, Tri Ton District, An Giang Province, 27/11/2014, coll. Nguyen Thanh Tung. Paratypes: 8 matures (CTU-EW.101.p02), same data as for the holotype.

Diagnosis: Small size worm, length 57-109 $\mathrm{mm}$, diameter ca. 3.2-4.6 mm. Body uniformly 
whitish. First dorsal pore in 12/13. Spermathecal pores multiple, dorsal in intersegments 4/5/6/7/8. Genital making large, paired on xix-xxiii. Copulatory pouches present. Intestinal caeca absent. Holandric.

Etymology: "alba" is an adjective in apposition to emphasize the whitish coloration of the species.

Description: External characters: Body cylindrical, the posteriormost part gradually tapering towards telson. Small size worm, length $57-109 \mathrm{~mm}$, diameter ca. 3.2-4.6 mm, weight $0.35-0.95 \mathrm{~g}$, segments 123-187. Body uniformly whitish. Prostomium epilobous (1/2). First dorsal pore in 12/13. Pre-clitellar setae stouter and thicker than post-clitellar setae,
55-86 in viii, 46-68 in $\mathrm{xxx}, 10-15$ between two male porophores; setae distance aa $=1$ 1.5ab, $\quad \mathrm{zz}=1.2-2.0 \mathrm{zy}$. Clitellum annular, xiv-xvi, opalescent, smooth, without setae and dorsal pores. Female pore single, mid-ventral on xiv.

Spermathecal pores multiple, dorsal in intersegmental furrows $4 / 5 / 6 / 7 / 8$, but pores in 7/8 almost invisible. Genital markings large, rectangular, ventrally paired on vi and vii. Male porophores highly elevated, male pores located inside copulatory pouches in xviii; ventral distance between two male pores about $0.35 \mathrm{x}$ body circumference. Genital markings large, 46 pairs on xix-xxiii, in line with male pores; anterior pairs smaller than posterior ones.
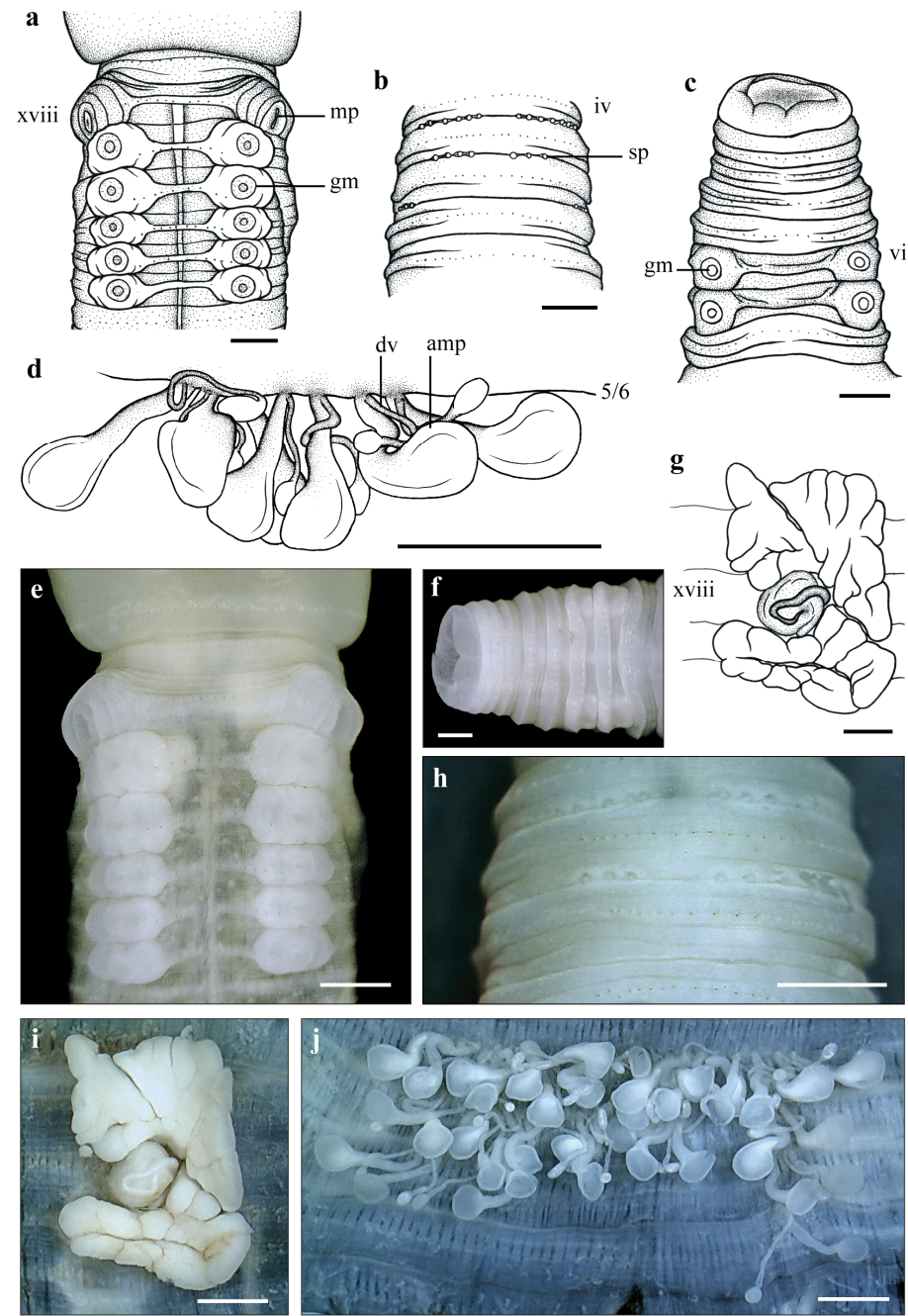

a, e: Male pore region $(\mathrm{mp}=$ male pore, $\mathrm{gm}=$ genital marking); $\mathrm{b}, \mathrm{h}$ : Spermathecal region, dorsal view ( $\mathrm{sp}=$ spermathecal pores); c, f: Spermathecal region, ventral view (gm = genital marking); d: Spermathecae in 5/6, right side ( $\mathrm{amp}=$ ampulla, $\mathrm{dv}=$ diverticulum); g, i: Prostate gland, right side; j: Spermathecae. Scale bar $=1 \mathrm{~mm}$. 
Table 1. Spermathecae number of Polypheretima alba sp. $\mathrm{n}$.

\begin{tabular}{|c|c|c|c|c|c|}
\hline Specimens & Position & Left & Right & & \\
\hline \multirow{4}{*}{ Holotype } & $4 / 5$ & 9 & 9 & 18 & \multirow{4}{*}{40} \\
\hline & $5 / 6$ & 7 & 9 & 16 & \\
\hline & $6 / 7$ & 2 & 3 & 5 & \\
\hline & $7 / 8$ & 1 & 0 & 1 & \\
\hline \multirow{4}{*}{ Paratype 1} & $4 / 5$ & 9 & 11 & 20 & \multirow{4}{*}{51} \\
\hline & $5 / 6$ & 9 & 11 & 20 & \\
\hline & $6 / 7$ & 3 & 5 & 8 & \\
\hline & $7 / 8$ & 2 & 1 & 3 & \\
\hline \multirow{4}{*}{ Paratype 2} & $4 / 5$ & 11 & 11 & 22 & \multirow{4}{*}{54} \\
\hline & $5 / 6$ & 9 & 10 & 19 & \\
\hline & $6 / 7$ & 6 & 4 & 10 & \\
\hline & $7 / 8$ & 2 & 1 & 3 & \\
\hline \multirow{4}{*}{ Paratype 3} & $4 / 5$ & 10 & 9 & 19 & \multirow{4}{*}{52} \\
\hline & $5 / 6$ & 9 & 9 & 18 & \\
\hline & $6 / 7$ & 7 & 6 & 13 & \\
\hline & $7 / 8$ & 1 & 1 & 2 & \\
\hline \multirow{4}{*}{ Paratype 4} & $4 / 5$ & 10 & 11 & 21 & \multirow{4}{*}{52} \\
\hline & $5 / 6$ & 11 & 9 & 20 & \\
\hline & $6 / 7$ & 6 & 3 & 9 & \\
\hline & $7 / 8$ & 1 & 1 & 2 & \\
\hline \multirow{4}{*}{ Paratype 5} & $4 / 5$ & 10 & 9 & 19 & \multirow{4}{*}{41} \\
\hline & $5 / 6$ & 8 & 7 & 15 & \\
\hline & $6 / 7$ & 3 & 3 & 6 & \\
\hline & $7 / 8$ & 0 & 1 & 1 & \\
\hline \multirow{4}{*}{ Paratype 6} & $4 / 5$ & 10 & 12 & 22 & \multirow{4}{*}{53} \\
\hline & $5 / 6$ & 8 & 10 & 18 & \\
\hline & $6 / 7$ & 4 & 6 & 10 & \\
\hline & $7 / 8$ & 1 & 2 & 3 & \\
\hline \multirow{4}{*}{ Paratype 7} & $4 / 5$ & 11 & 10 & 21 & \multirow{4}{*}{57} \\
\hline & $5 / 6$ & 8 & 10 & 18 & \\
\hline & $6 / 7$ & 8 & 6 & 14 & \\
\hline & $7 / 8$ & 3 & 1 & 4 & \\
\hline \multirow{4}{*}{ Paratype 8} & $4 / 5$ & 12 & 12 & 24 & \multirow{4}{*}{56} \\
\hline & $5 / 6$ & 10 & 9 & 19 & \\
\hline & $6 / 7$ & 6 & 4 & 10 & \\
\hline & $7 / 8$ & 1 & 2 & 3 & \\
\hline
\end{tabular}

Internal characters: Septa 5/6/7/8 thickened, 8/9/10 absent, 10/11/12 thin. Oesophageal gizzard within viii-ix. Intestinal origin at $\mathrm{xv}$; caeca absent. Last hearts in xiii. Pharyngeal micronephridia poorly developed on septum 5/6, and more developed on septum 6/7. Lymph glands present from 15/16, sacculeshaped. Typhlosole simple, lamelliform.

Spermathecae variable, about 41-57 altogether in v-viii: $18-24$ in v, 15-20 in vi, 6-14 in vii, $1-4$ in viii (table 1). Spermathecal ampulla oval-shaped; duct long, ca. 2/3 ampulla length. Diverticula shorter than ampulla; distal part enlarged to be an opalescent seminal chamber; duct attached to base of ampulla. Accessory gland absent in the spermathecal region.

Holandric. Testes sacs developed in $\mathrm{x}$-xi, 
separated. Seminal vesicles well developed, paired in xi-xii. Ovaries on septum 12/13 posteriorly; ovisacs well developed, opalescent in $12 / 13$. Prostate glands deeply lobuled, paired in xvii-xix, or xvii-xx; prostatic ducts slightly smaller towards pores. Accessory absent in the male region.

Locality and habitat: This species was found in a mango garden in Co To mountain (Tri Ton District). They usually live in soils with high humidity and mould. Their casts are small and twisted lumps.

Remarks: The new species is fairly similar to Polypheretima elongata (Perrier, 1872) in having numerous genital markings pairedly arranging on segment xix onwards. However, Po. elongata differs from this new species in having spermathecal pores in ventrolaterally intersegmental furrows $5 / 6 / 7$ and no genital markings on the spermathecal region. In contrast, the new species has spermathecal pores in dorsally intersegmental furrows $4 / 5 / 6 / 7 / 8$ and genital markings paired on vi and vii.

In comparison to other polythecal species, the new species is close to Po. koyana (Michaelsen, 1934a), Po. lesonea Easton, 1979 and Po. polytheca (Beddard, 1900) in having four spermathecal segments and genital markings pairedly arranging on the male region. However, the new species is distinguished from other similar species by spermathecal pores in dorsal 4/5/6/7/8 and 4-6 pairs of genital markings on xix-xxiii. Three species, Po. koyana, Po. lesonea and Po. polytheca, differ from the new species in spermathecal pores in lateroventral or ventral 5/6/7/8/9, and genital markings paired on xvii, xix, xx (in $P o$. koyana), or on xvii, xix-xxii (in Po. lesonea) or on xviii, xix (in Po. polytheca). Character comparison among four species ispresented in table 2 .

Table 2. Comparison of the characters among Po. alba, Po. koyana, Po. lesonea and Po. polytheca

\begin{tabular}{|c|c|c|c|c|c|}
\hline No. & Characters & Po. alba & Po. koyana & Po. lesonea & Po. polytheca \\
\hline 1 & Length (mm) & $57-109$ & $175-225$ & $73-88$ & $44-50$ \\
\hline 2 & Diameter (mm) & $3.2-4.6$ & $3.5-4$ & $2-3$ & $1.5-2$ \\
\hline 3 & First dosal pore & $12 / 13$ & $12 / 13$ & $11 / 12$ & $12 / 13$ \\
\hline 4 & $\begin{array}{l}\text { Spermathecal } \\
\text { pores }\end{array}$ & $\begin{array}{c}4 / 5 / 6 / 7 / 8 \\
\text { dorsally }\end{array}$ & $\begin{array}{c}5 / 6 / 7 / 8 / 9 \\
\text { ventrolaterally }\end{array}$ & $\begin{array}{c}5 / 6 / 7 / 8 / 9, \\
\text { ventrolaterally }\end{array}$ & $\begin{array}{l}5 / 6 / 7 / 8 / 9 \\
\text { ventrally }\end{array}$ \\
\hline 5 & $\begin{array}{l}\mathrm{GM} \text { in } \\
\text { spermathecal } \\
\text { region }\end{array}$ & $\begin{array}{l}2 \text { pairs, } \\
\text { vi - vii }\end{array}$ & $\begin{array}{l}2 \text { pairs, } \\
\text { vii - viii }\end{array}$ & absent & 2 pairs, vi - viii \\
\hline 6 & $\begin{array}{l}\text { GM in male } \\
\text { pore region }\end{array}$ & $\begin{array}{l}\text { 4-6 pairs, } \\
\text { xix-xxiii }\end{array}$ & $\begin{array}{c}3 \text { pairs, } \\
\text { xvii, xix, } x x\end{array}$ & $\begin{array}{c}5 \text { pairs, } \\
\text { xvii, xix-xxii }\end{array}$ & $\begin{array}{l}2 \text { pairs in } \\
\text { xviii, xix }\end{array}$ \\
\hline 7 & Last hearts & xiii & xiii & xiii & xii \\
\hline 8 & Spermatheacae & $41-57$ in total & $\begin{array}{l}\text { Maximum } \\
\text { 9/segment }\end{array}$ & $\begin{array}{l}1 \text { pair/segment } \\
\text { in vi-viii, } \\
\text { numerous in ix }\end{array}$ & $6-10$ in total \\
\hline
\end{tabular}

GM: genital markings.

\section{REFERENCES}

Nguyen Duc Anh, Nguyen Thanh Tung, 2015. Notes on Metaphire multitheca (Chen, 1938) (Oligochaeta, Megascolecidae) recorded from Vietnam, with descriptions of two new species. ZooKeys, 506: 127-136.

Thai Tran Bai, Do Van Nhuong, Huynh Thi Kim Hoi, 1993. New species of earthworms of genus Pheretima Kinberg, 1867 (Megascolecidae - Oligochaeta) from Yokdon, Daclac province. Tap chi Sinh hoc, 15(4): 12-15.

Thai Tran Bai, Samphon K., 1988. New species and subspecies of earthworms from Laos. Journal of Science of HNUE, C: 3-24.

Thai Tran Bai, Samphon K., 1989. Initial 
remarks on the fauna of earthworms in Laos (from Muong Phuon to Bualaven plateux). Journal of Science of HNUE, special issue: 61-75.

Beddard F. E., 1900. On the Earthworms collected during the "Skeat Expedition" to the Malay Peninsula, 1899-1900. Proceedings of the Zoological Society of London, 1900: 891-911.

Easton E. G., 1979. A Revision of the "acaecate" Earthworms of the Pheretima Group (Megascolecidae: Oligochaeta): Archipheretima, Metapheretima, Planapheretima, Pleionogaster, and Polypheretima. British Museum (Natural History), 35: 1-126.

Michaelsen W., 1934a. Oligochaeta from Sarawak. Quarterly Journal of Microscopical Science, 77: 1-47.

Michaelsen W., 1934b. Oligochäten von Franzosisch-Indochina. Archs. Zool. Exp. Gen, 76: 493-456.

Perrier E., 1872. Recherches pour servir à l'histoire des Lombriciens terrestres. Nouvelles Archives du Muséum d'Histoire Naturelle de Paris, 8: 5-198.

Rosa D., 1890. Viaggio di Leonardo Fea in Birmanica e regioni vicini, XXVI. Perichaetidi. Annali del Museo civico di storia naturale Giacomo Doria, 10: 107-122.

Stephenson, J. 1931. Oligochaeta from Burma, Kenya, and other parts of the world. Proceedings of the Zoological Society of London, 101(1): 33-92.

Le Thong, 2006. Geography of Provinces and Cities of Vietnam (Volume 6). Vietnam Education Publishing House, Hanoi, Vietnam, pp. 579.

Nguyen Thanh Tung, 2011. Descriptions of two new species of earthworm of the genus Pheretima Kinberg, 1867 (Oligochaeta: Megascolecidae) from Mekong DeltaVietnam. Tap chi Sinh hoc, 33(1): 24-29.

Nguyen Thanh Tung, Trinh Thi Kim Binh, Le Van Nhan, Nguyen Duc Anh, 2015. On the polythecate earthworms of the genus Metaphire (Oligochaeta: Megascolecidae) from Vietnam, with descriptions of three new species. Raffles Bulletin of Zoology, 63: 461-470.

Nguyen Thanh Tung, Nguyen Thi Kim Phuoc, Ho Minh Thuan, 2012. The diversity and distribution of eathworms in An Giang province. Journal of Science of Can Tho University, 22a: 144-153.

Nguyen Thanh Tung, Tran Thi Anh Thu, 2008. Composition and distribution of earthworms in the belt of Tien river. Journal of Science of Can Tho University, 10: 59-66.

\title{
HAI LOÀI GIUN ĐẤT MỚI (Oligochaeta, Megascolecidae) Ở VIẸTT NAM
}

\author{
Nguyễn Thanh Tùng \\ Bộ môn Sư phạm Sinh học, Khoa Sư phạm, Trường Đại học Cần Thơ
}

\section{TÓM TẮT}

Bài báo mô tả 2 loài giun đất mới thuộc giống Metaphire Sims \& Easton, 1972 và Polypheretima Michaelsen, 1934, đó là Metaphire nhuongi sp. n. và Polypheretima alba sp. n.. Metaphire nhuongi sp. n. là loài có kích thước lớn nhất được ghi nhận ở Đồng bằng sông Cửu Long cho đến nay. Loài này có 4 đôi lỗ nhận tinh ở phía bên bụng ở rãnh gian đốt 5/6/7/8/9, 2 đôi nhú phụ sinh dục ở rãnh gian đốt 17/18 và 18/19. Polypheretima alba sp. n. khác biệt so với các loài cùng giống ở đặc điểm nhiều lố nhận tinh phía lưng ở 4/5/6/7/8, cơ thể màu trắng trong, nhú phụ sinh dục xếp thành từng đôi (có từ 4 đến 6 đôi từ đốt xix-xxiii).

Tù khóa: Megascolecidae, Metaphire, Polypheretima, giun đất, loài mới, Việt Nam. 